\title{
Gametogenesis, seasonal reproduction and imposex of Adelomelon beckii (Neogastropoda: Volutidae) in Mar del Plata, Argentina
}

\author{
Florencia Arrighetti ${ }^{1,2, *}$, Pablo E. Penchaszadeh ${ }^{1,2}$ \\ ${ }^{1}$ Consejo Nacional de Investigaciones Científicas y Técnicas (CONICET), Museo Argentino de Ciencias Naturales, \\ Av Angel Gallardo 470 (1405), Buenos Aires, Argentina \\ ${ }^{2}$ Facultad de Ciencias Exactas y Naturales, Universidad de Buenos Aires, Buenos Aires, Argentina
}

\begin{abstract}
Adelomelon beckii (Broderip, 1836) (Neogastropoda: Volutidae) is endemic to the western south Atlantic coast. It inhabits sandy bottoms in waters between 40 and $70 \mathrm{~m}$ deep and is one of the largest top benthic predators found in Mar del Plata, Argentina. The present study describes gametogenesis and the reproductive cycle of this species. Oocytes developed in close association with follicle cells, which appear to play a role in yolk synthesis and oocyte resorption, providing the key functions of phagocytosis and intracellular digestion of degenerating oocytes. Spermatogenesis resembles that reported for other volutids. The reproductive cycle of $A$. beckii in Mar del Plata was studied over a period of 2 yr (September 2004 to August 2006). Gametic emission in males continued throughout the year while females showed 2 spawning periods: one during spring (September-November) and another during autumn (March-April). In females, this semi-annual pattern appears to be related to the seasonal variation in seawater temperature, coinciding with observations made in other volutes. In males, there was no relationship to variation in seawater temperature, an unusual pattern for a species from a temperate region. Imposex was described for the first time in this species. These data constitute baseline information for establishing appropriate and biologically based management and conservation strategies for this overexploited gastropod species.
\end{abstract}

KEY WORDS: Adelomelon beckii $\cdot$ Gametogenesis $\cdot$ Reproductive cycle $\cdot$ Volutidae $\cdot$ Imposex

Resale or republication not permitted without written consent of the publisher

\section{INTRODUCTION}

Volutids are an important fishery resource on the continental shelf of Argentina (Giménez et al. 2005) and Uruguay (Riestra \& Fabiano 2000). The giant snail Adelomelon beckii (Broderip, 1836) is endemic to the western south Atlantic coast and is distributed from Espíritu Santo (Brazil) to Tierra del Fuego (Argentina) (Weaver \& du Pont 1970). This species inhabits sandy bottoms in water depths between 40 and $70 \mathrm{~m}$ (Weaver $\&$ du Pont 1970), often exceeding $40 \mathrm{~cm}$ and sometimes reaching up to $51 \mathrm{~cm}$ in shell length (Rios 1994). A. beckii has low population densities (Carranza et al. 2008) and is one of the top benthic predators found within the study area (Arrighetti 2009). This species has been caught as bycatch of bottom trawlers, but in recent years has become a target species for artisanal fishermen. Its large muscular foot is used for human consumption and its large attractive shell is sold in local and international markets as an artisanal product. Despite its impressive size and increasing importance as a fishery resource, little is known about its biology, except for some ultrastructural aspects of reproduction (Giménez et al. 2009, Arrighetti \& Giménez 2010). Previous studies have focused on aspects such as reproduction, growth and fishery of several volutids (Zidona dufresnei, Giménez \& Penchaszadeh 2002, Giménez et al. 2004, 2005; A. brasiliana, Cledón et al. 2005a,b; Odontocymbiola magellanica, Bigatti et al. 2007, 2008; A. ancilla, Penchaszadeh et al. 2009), and imposex has been documented for all of them, except for $Z$. dufresnei (Bigatti et al. 2009). 
In this context, the aim of the present study is to describe gametogenesis and the reproductive cycle of Adelomelon beckii using histological and ultrastructural techniques, and to provide information about the existence of imposex. The present data constitute baseline information for establishing appropriate and biologically based management and conservation strategies for this gastropod species.

\section{MATERIALS AND METHODS}

Samples of Adelomelon beckii were collected monthly from September 2004 to August 2006 by bottom trawling in the Mar del Plata area $\left(38^{\circ} 20^{\prime} \mathrm{S}\right.$, $57^{\circ} 37^{\prime} \mathrm{W}$ ) at depths from 40 to $70 \mathrm{~m}$. Fifteen to 20 snails ranging from 20.0 to $39.0 \mathrm{~cm}$ in total shell length (SL) (i.e. sexually developed animals, Arrighetti 2009) were caught each month. In the laboratory, each individual was measured for SL with vernier calipers to the nearest $\mathrm{mm}$ and weighed for shell-free wet mass (SFWM) to the nearest $\mathrm{g}$. Sex was identified by the difference in gonad colour, presence or absence of a penis and secondary sexual characteristics (albumen and capsule gland). To establish the morphometric relationship between SL and SFWM for each sex, linear regression analyses were performed using $\log ($ SFWM $)=\log$ a + $\mathrm{b} \times \log (\mathrm{SL})$. Parallelism tests and analysis of covariance (ANCOVA) were performed to compare the relationship between SFWM and SL between sexes. The sex ratio was compared to parity (1:1) with the $\chi^{2}$ test.

After removal from the shell, a small piece of the gonad for both sexes was fixed in Bouin's solution for $3 \mathrm{~h}$ at room temperature and subsequently stored in $70 \%$ alcohol. Tissues were dehydrated using an ascending series of ethanol concentrations and then embedded in resin (Leica Histoplast). Sections were cut at $5 \mu \mathrm{m}$ with an electronic microtome (Leica), stained with hematoxylin and eosin and observed under a light microscope (Zeiss Axio Imager Z1). For electron microscopy, a small piece of female gonad was fixed in $3 \%$ glutaraldehyde in $0.1 \mathrm{M}$ sodium phosphate buffer containing $0.1 \% \mathrm{CaCl}_{2}$ (for $4 \mathrm{~h}$ at $4^{\circ} \mathrm{C}$ ) and washed in phosphate buffer. Subsequently, these tissues were placed in a $1 \%$ solution of osmium tetroxide in $0.1 \mathrm{M}$ sodium phosphate buffer for $1.5 \mathrm{~h}$, again buffer-rinsed, ethanoldehydrated and embedded in Spurr's resin. Ultrathin sections were cut using either a Reichert or an LKB IV ultramicrotome and stained with uranyl acetate and lead citrate. Sections were examined and photographed using Zeiss EM 109T, Hitachi 300 and Jeol 1010 transmission electron microscopes operated at 75 to $80 \mathrm{kV}$.

The oocytes were classified according to their gametogenic developmental stage. To study monthly gonadal development, oocyte size was calculated from the mean of 2 diameters (taken at right angles to each other) measured in 50 oocytes with conspicuous nucleoli. For each female, a smear of the interior part of the bursa copulatrix (the organ where the male deposits sperm during copulation) was examined microscopically. For each male, 2 slides were prepared to describe spermatogenesis and gonadal development. The seminal vesicle was dissected and analyzed to determine the presence/absence of spermatozoa.

To determine the occurrence of imposex in this population of Adelomelon beckii, specimens of both sexes collected throughout the study period were analyzed. After sexing the individuals, penis length was measured in imposex-affected females and males using vernier calipers. The degree of imposex was determined using 2 indices-relative penis length index $($ RPLI $=$ [female penis mean length/male penis mean length] $\times 100$ ) and vas deference sequence (VDS)both calculated according to Gibbs \& Bryan (1994). The percentage of imposex-affected females $(I)$ was calculated as: $I=$ (number of females with imposex/ total number of females) $\times 100$.

\section{RESULTS}

\section{Sex ratio and population structure}

Sex was clearly identified in all individuals examined. The overall sex ratio was significantly different from $1: 1\left(\chi^{2}=15.22, \mathrm{df}=1, \mathrm{p}<0.05\right)$ and the sex ratio also displayed significant differences from 1:1 in most of the monthly samples (Fig. 1A), except in December 2005 when no males were sampled. A discernible trend was found in the variation of sex ratio throughout the year, with a predominance of females during September, October and November of both years. Females ranged from 23 to $39 \mathrm{~cm}$ SL and males ranged between 20 and $36.5 \mathrm{~cm}$ SL. The relationships established for both sexes between SL and SFWM are shown in Table 1; no significant differences were detected in the parallelism test $(p>0.05)$, but the ANCOVA revealed significant differences between sexes $(p<0.05)$. Females reached a larger size than males (Fig. 1B).

\section{Gonadal structure and gametogenesis}

\section{Females}

The brownish-coloured ovary was situated in the inner-dorsal surface of the digestive gland where it was embedded, thus not allowing for the calculation of the gonadosomatic index. The ovary is a multi-tubular organ; each tubule was surrounded by connective 

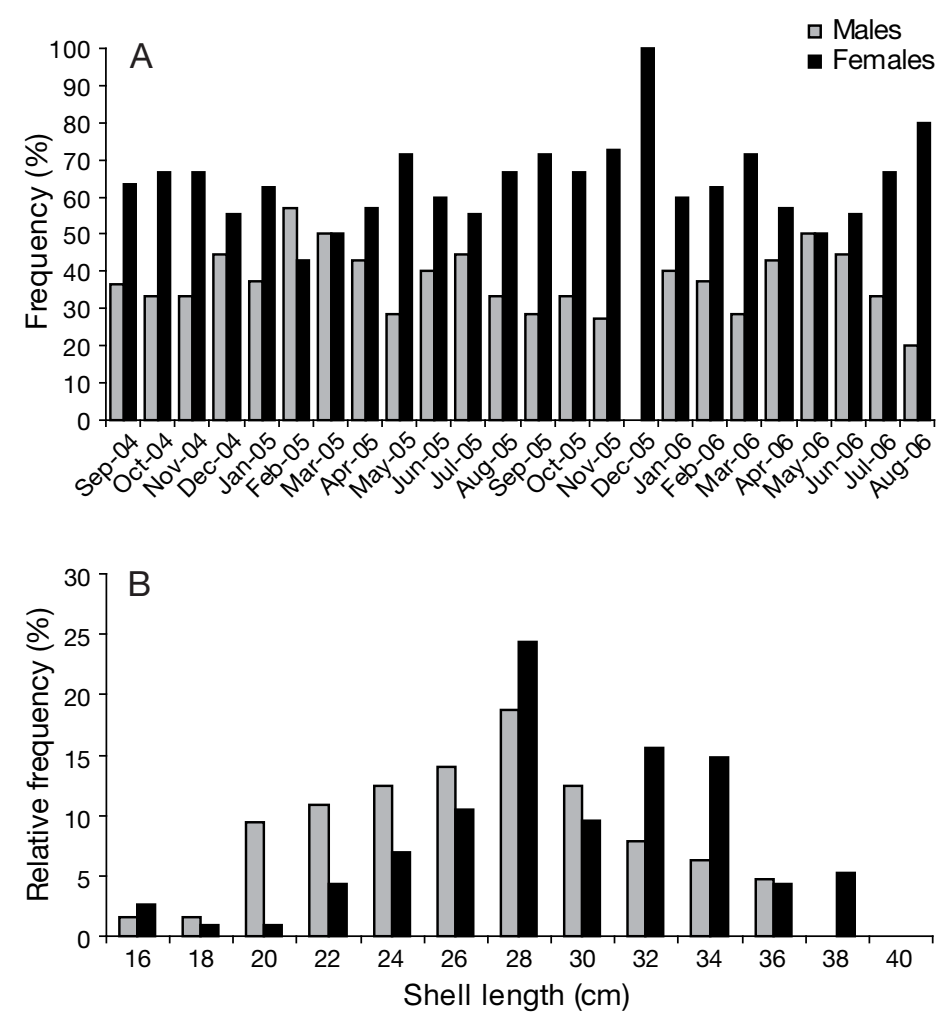

Fig. 1. Adelomelon beckii. (A) Sex ratio and (B) length-frequency distribution of $A$. beckii males and females from Mar del Plata during the study period September 2004 to August 2006

tissue and contained follicle cells and oocytes in different developmental stages. Follicle cells were in close contact with all oocytes, always completely surrounding them. Their nuclei were spherical and contained patches of heterochromatin (Fig. 2A,B). Their cytoplasm contained mitochondria and extensive rough endoplasmic reticulum; lysosomal-like inclusions were often observed (Fig. 2A,B). Follicle cells and oocytes were not in cytoplasmatic continuity, although some gap junctions were observed (Fig. 2C). Follicle cells were joined together by desmosomes (Fig. 2D).

Based on electron microscopy observations, 4 different phases of oogenesis were recognized: oogonia, previtellogenic oocytes, vitellogenic oocytes and oocyte degeneration and resorption. The oogonia, which measured 10 to $30 \mu \mathrm{m}$ in diameter, were round in shape. Each possessed a large ovoid nucleus and several mitochondria; endoplasmic reticulum and vac- uoles appeared in the cytoplasm (Fig. 3A). Oogonia developed into previtellogenic oocytes which measured 30 to $60 \mu \mathrm{m}$ in diameter and were oval in shape. In this phase, endoplasmic reticulum and mitochondria were concentrated within the cytoplasm (Fig. 3B). At about $60 \mu \mathrm{m}$ in diameter, lipid droplets, endoplasmic reticulum, mitochondria and the Golgi complex appeared in the cytoplasm of early vitellogenic oocytes (Fig. 3C). This stage indicated the onset of yolk synthesis. Several pinocytic vesicles were seen between the vitellogenic oocyte and the follicle cell, indicating endocytosis of nutrients (Fig. 3D). The cytoplasm of late vitellogenic oocytes was characterized by the presence of protein yolk granules and lipid droplets (Fig. 3E). Degeneration of oocytes was only observed in vitellogenic oocytes. The degenerating oocytes were slightly irregular in shape. The endoplasmic reticulum was the first organelle involved in the degenerative process; it became distended, leading to vacuolization of the cytoplasm (Fig. 3F). Yolk granules disintegrated in the cytoplasm, and several vacuoles and phagosomes appeared (Fig. 3G). At this particular stage, a few phagosomes appeared in the cytoplasm of the follicle cells. At the end of this stage, the oocytes became disintegrated and follicle cells were observed in their place.

\section{Males}

The orange to brown testis of Adelomelon beckii was situated dorsally to the digestive gland. It consisted of a mass of tubules, which were separated from each other by connective tissue (Fig. 4A). The seminal vesicle was contiguous to the testis, but sometimes was observed embedded in it (Fig. 4B). The seminal vesicle was filled by spermatozoa throughout the entire year, thus the gonadosomatic index was not a good indicator of gonadal changes and did not give a reliable description of the periods of gametic emission. In general, spermatogenic cells were clustered in small groups irregularly distributed within the tubules (Fig. 4C). The spermatogonia and spermatocytes were situated in close contact with the tubule wall, while

Table 1. Adelomelon beckii. Relationships established between shell length (SL) and shell-free wet mass (SFWM) of male and female A. beckii

\begin{tabular}{|c|c|c|c|c|c|}
\hline Sex & $\begin{array}{l}\text { Mean SL } \\
\text { (cm) }\end{array}$ & $\begin{array}{c}\text { Mean SFWM } \\
(\mathrm{kg})\end{array}$ & Regression equation & $\mathrm{R}^{2}$ & $\mathrm{p}$ \\
\hline Male & $27.32 \pm 4.33$ & $1.29 \pm 0.60$ & $\log (\mathrm{SFWM})=-4.03+2.86 \log (\mathrm{SL})$ & 0.86 & $<0.0001$ \\
\hline Female & $30.25 \pm 4.75$ & $1.81 \pm 0.78$ & $\log (\mathrm{SFWM})=-3.60+2.59 \log (\mathrm{SL})$ & 0.84 & $<0.0001$ \\
\hline
\end{tabular}




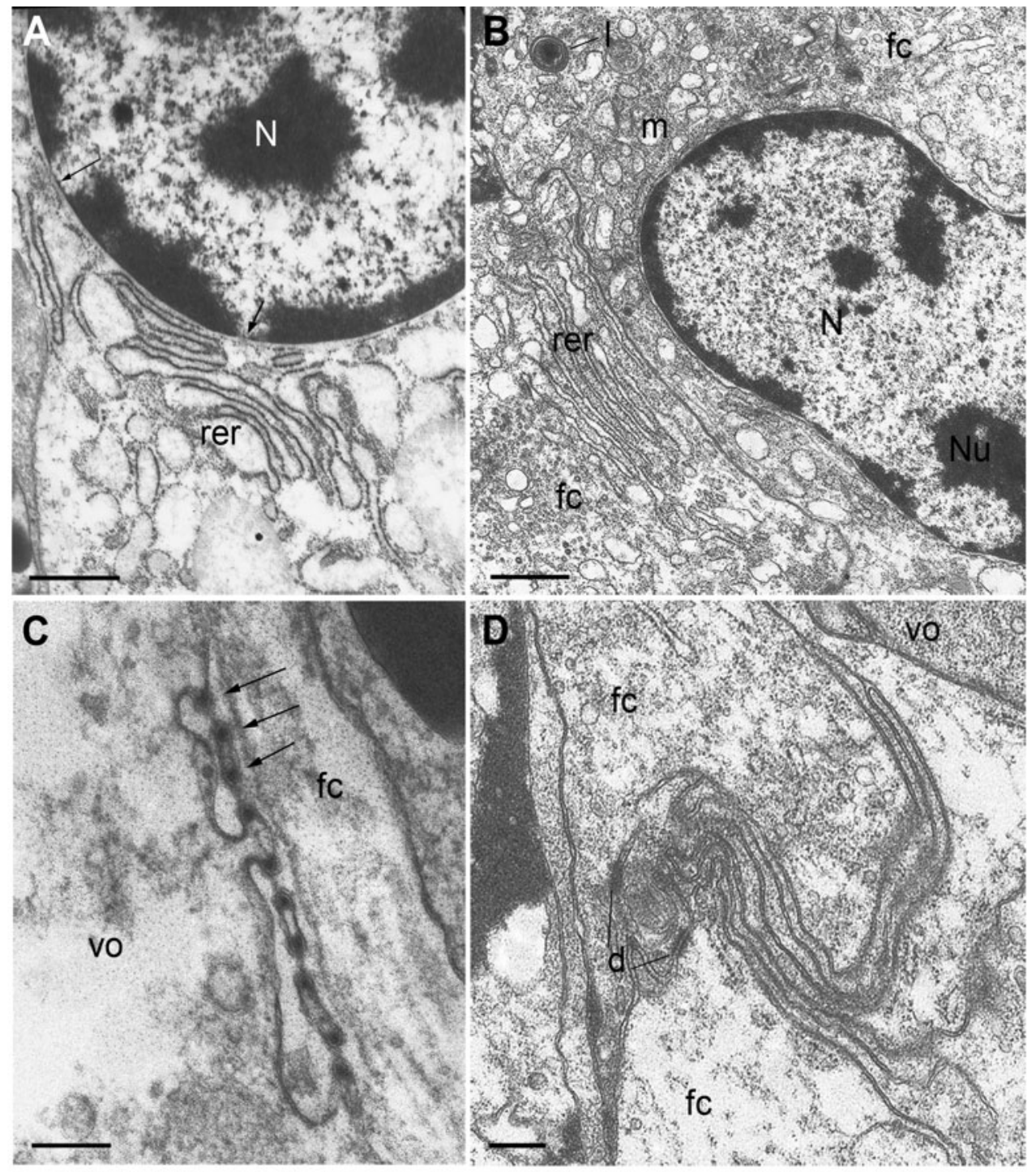

Fig. 2. Adelomelon beckii. Electron micrographs of follicle cells. (A) Follicle cell with a large nucleus (N), nuclear pores (arrows) and rough endoplasmic reticulum (rer) in the cytoplasm. (B) Two follicle cells (fc); note the presence of a nucleolus (Nu) in the nucleus $(\mathrm{N})$ and the cytoplasm with rough endoplasmic reticulum (rer), mitochondria $(\mathrm{m})$ and lysosome-like inclusions (l). (C) Gap junction (arrows) between the follicle cell (fc) and the vitellogenic oocyte (vo). (D) Micrograph showing desmosomes (d) between 2 follicle cells (fc). Scale bars: (A) $2 \mu m_{i}$ (B) $2.5 \mu m_{i}$ (C) $0.2 \mu m_{i}$ (D) $1 \mu \mathrm{m}$

spermatids were located near the lumen (Fig. 4C). Two main types of spermatic cells were found in the same tubule: spermatozoa and paraspermatozoa (Fig. 4D). For an ultrastructural description of spermatogenesis in A. beckii see Arrighetti \& Giménez (2010).

\section{Gonadal development}

Females

Based on histological observations, the gametogenic cycle was classified according to 5 stages of gonadal development: early development, late development, mature, spent and recovering. During early development, the ovary was characterized by the presence of round oogonia and previtellogenic oocytes (Fig. 5A). As maturation advanced, the ovary increased in size and early vitellogenic (60 to $80 \mu \mathrm{m}$ in diameter) and vitellogenic oocytes were observed (Fig. 5B). When the ovary became mature, the tubules were full of yolkcontaining vitellogenic oocytes measuring $>100 \mu \mathrm{m}$ in diameter (Fig. 5C,D). In spent ovaries, most mature oocytes were released, although a few residual mature oocytes remained along with the appearance of new developing oocytes with diameters $<80 \mu \mathrm{m}$ in diameter 

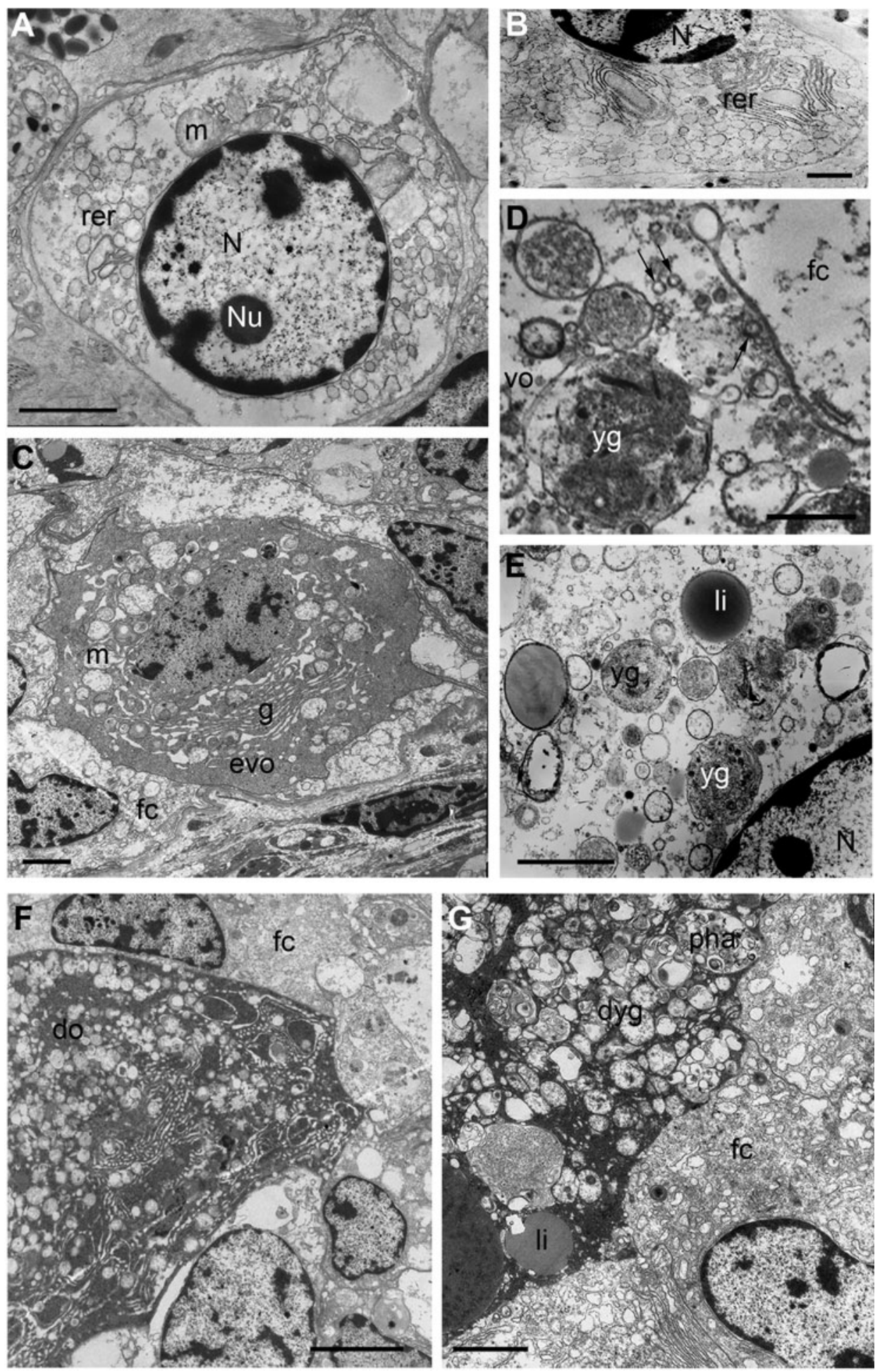

Fig. 3. Adelomelon beckii. Electron micrographs of oogenesis and oocyte degeneration. (A) Oogonia, with a nucleolus (Nu) in the nucleus (N) and several mitochondria $(\mathrm{m})$ and rough endoplasmic reticulum (rer) in the cytoplasm. (B) Previtellogenic oocyte with nucleus $(\mathrm{N})$ and extensive arrays of rough endoplasmic reticulum (rer) in the cytoplasm. (C) Early vitellogenic oocytes (evo) and attached follicle cells (fc), mitochondria (m) and Golgi complex (g) in the cytoplasm of the oocyte. (D) Vitellogenic oocyte (vo) in close contact with a follicle cell (fc), showing pinocytic vesicles (arrows) and yolk granules (yg). (E) Vitellogenic oocyte showing yolk granules (yg) and lipid droplets (li). (F) Degenerating oocyte and the attached follicle cells (fc), showing the vacuolization of the cytoplasm of the oocyte. (G) Oocyte in resorption surrounded by follicle cells (fc) with phagosomes (pha), lipid droplets (li) and degenerating yolk granules (dyg). Scale bars: (A) $2 \mu \mathrm{m}_{\text {; (B) }} 1.5 \mu \mathrm{m}_{i}(\mathrm{C}, \mathrm{G}) 5 \mu \mathrm{m}$; (D) $1 \mu \mathrm{m}$; (E) $3 \mu \mathrm{m}$; (F) $10 \mu \mathrm{m}$ 

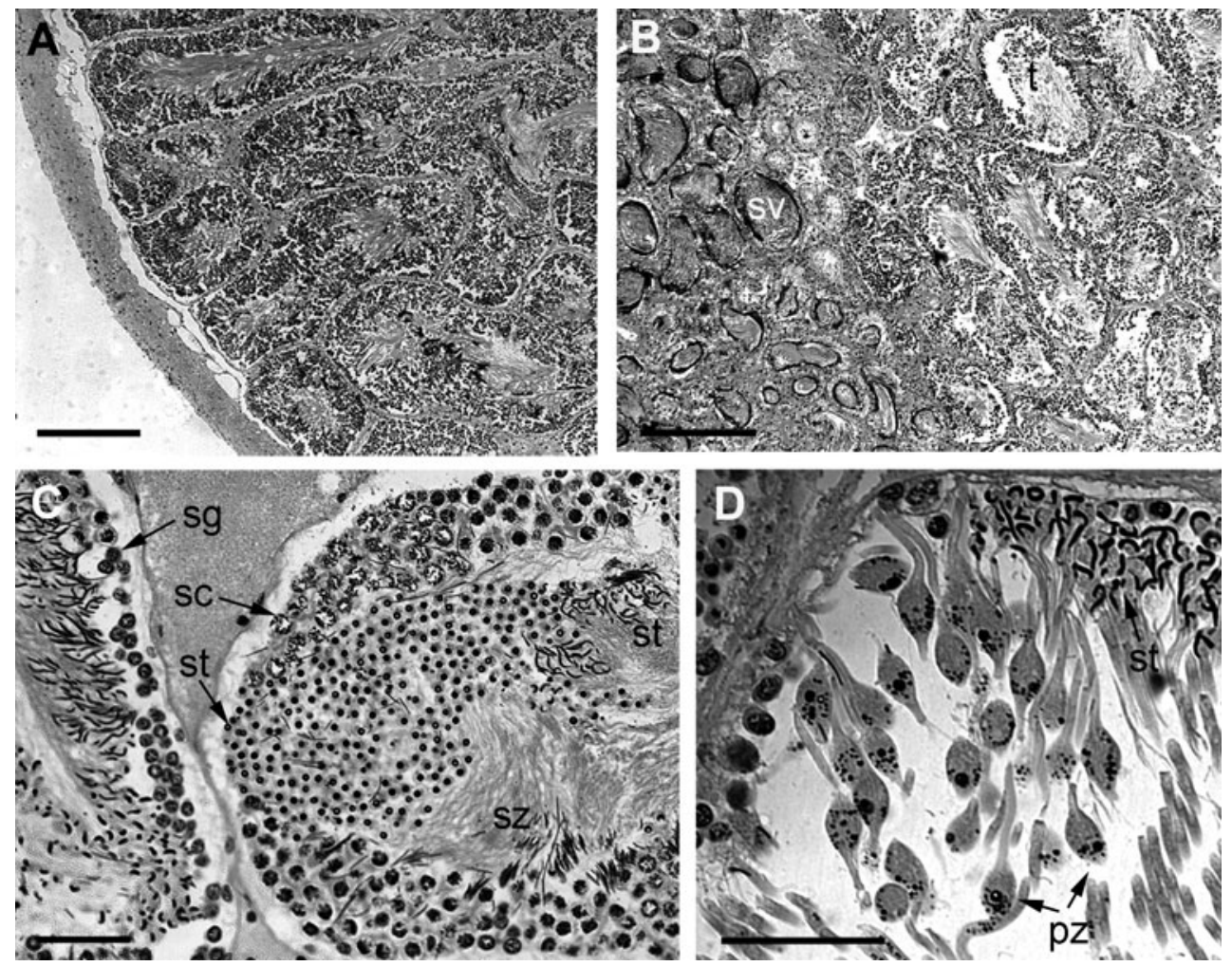

Fig. 4. Adelomelon beckii. Histology of male gonad. (A) General view of the testis showing spermatogenic tubules. (B) Testis (t) and contiguous seminal vesicle (sv). (C) Tubule with the entire spermatic series: spermatogonia (sg), spermatocytes (sc), spermatids (st) and spermatozoa (sz). (D) Detail of a spermatogenic tubule showing paraspermatozoa (pz). Scale bars: (A,B) $400 \mu$ m;

(C,D) $50 \mu \mathrm{m}$

(Fig. 5E). The recovering stage was characterized by empty tubules and the undischarged oocytes underwent resorption. At the same time new oogonia were observed (Fig. 5D).

\section{Males}

The gametogenic cycle was divided in 4 developmental stages: developing, mature, spent and recovering. During the developing stage the testis was characterized by the presence of spermatocytes; in addition, spermatogonia, spermatids and sometimes some spermatozoa were present (Fig. 6A). In the mature stage, the tubules were full of spermatozoa, which formed a dense mass in the center of the lumen (Fig. 6B). Additionally, zones with spermatogonia, spermatocytes and spermatids indicated that gametogenesis continued in the tubular wall. In the spent stage, the lumen of the tubules was empty and few spermatozoa were found; spermatocytes and spermatids formed a thin wall (Fig. 6C). The recovering stage was characterized by the presence of few spermatozoa free in the lumen of the tubules and signs of degradation were apparent (Fig. 6D).

\section{Reproductive cycle}

The monthly frequency of females in each developmental stage is summarized in Fig. 7A. Females were in the developing stage during the entire study period, except for April 2006. During September 2004, the ovary contained oocytes of all sizes, from 10 to $175 \mu \mathrm{m}$ in diameter (Table 2), with the cytoplasm full of yolk granules. In October 2004 a decrease in the mean oocyte diameter indicated a spawning period that continued until November. In December 2004 and January 2005 a recovery period began, with the presence of residual bodies, a product of degenerated oocytes. After January, oocytes started to grow, and a less intense spawning period was observed during March and April. In April 2005, residual mature oocytes that were not spawned began to degenerate, and new developing oocytes grew up to $213 \mu \mathrm{m}$ in diameter in July. An extended spawning period occurred between September and November 2005, which was followed by a developing period during January and February 2006, although some mature oocytes were present during the developing period. Following this phase, a new spawning period began and continued until April 

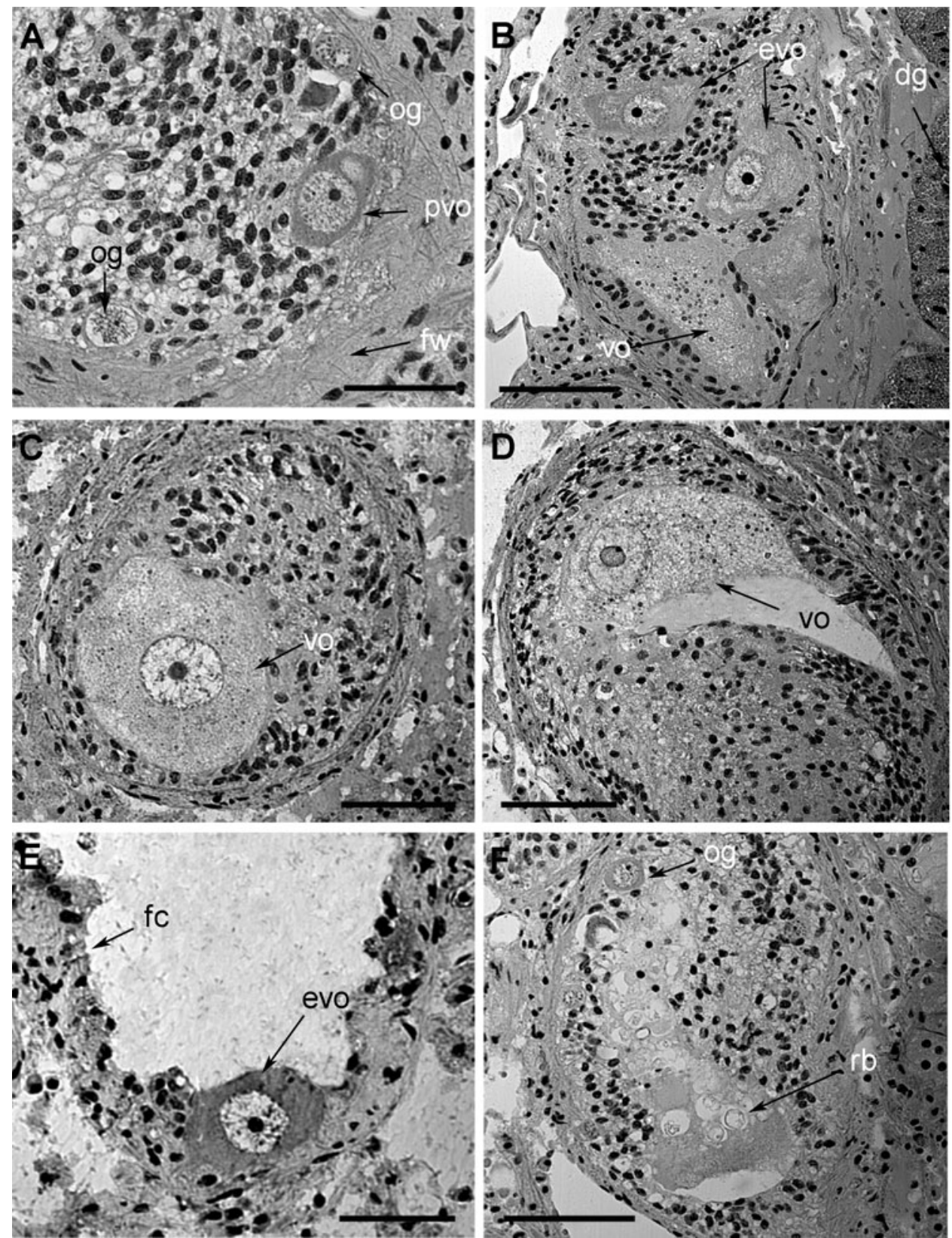

Fig. 5. Adelomelon beckii. Histology of female gonad showing developmental stages. (A) Early developing: oogonia (og) attached to the follicular wall (fw) and previtellogenic oocytes (pvo). (B) Late developing: follicles with early vitellogenic oocytes (evo) and vitellogenic oocytes (vo), note the near presence of the digestive gland (dg). (C,D) Mature: vitellogenic oocytes (vo) occupying almost the entire follicle. (E) Spent: follicle cells (fc) along with new early developing oocyte (evo). (F) Recovering: oocyte undergoing lysis; note the presence of residual bodies (rb) together with new oogonia (og). Scale bars: (A,E) $50 \mu \mathrm{m}$; (B-D, F) $100 \mu \mathrm{m}$

2006. Live spermatozoa were present in the bursa copulatrix during the entire study period.

The monthly frequency of males in each developmental stage is illustrated in Fig. 7B. In all monthly samples, each spermatic tubule contained all stages of spermatogenesis, indicating a continuous production of spermatozoa throughout the year. The mature stage was observed during almost all of the study period, even though different maturation stages were seen in most individuals. A partial emission of spermatozoids was observed during the 2 yr. After the liberation of the mature sperm, the testis remained empty with few residual spermatozoa in the lumen. Seminal vesicle tubules were full of sperm throughout the 2 yr study period. The maximum proportion of individuals in the recovering stage occurred in January. 

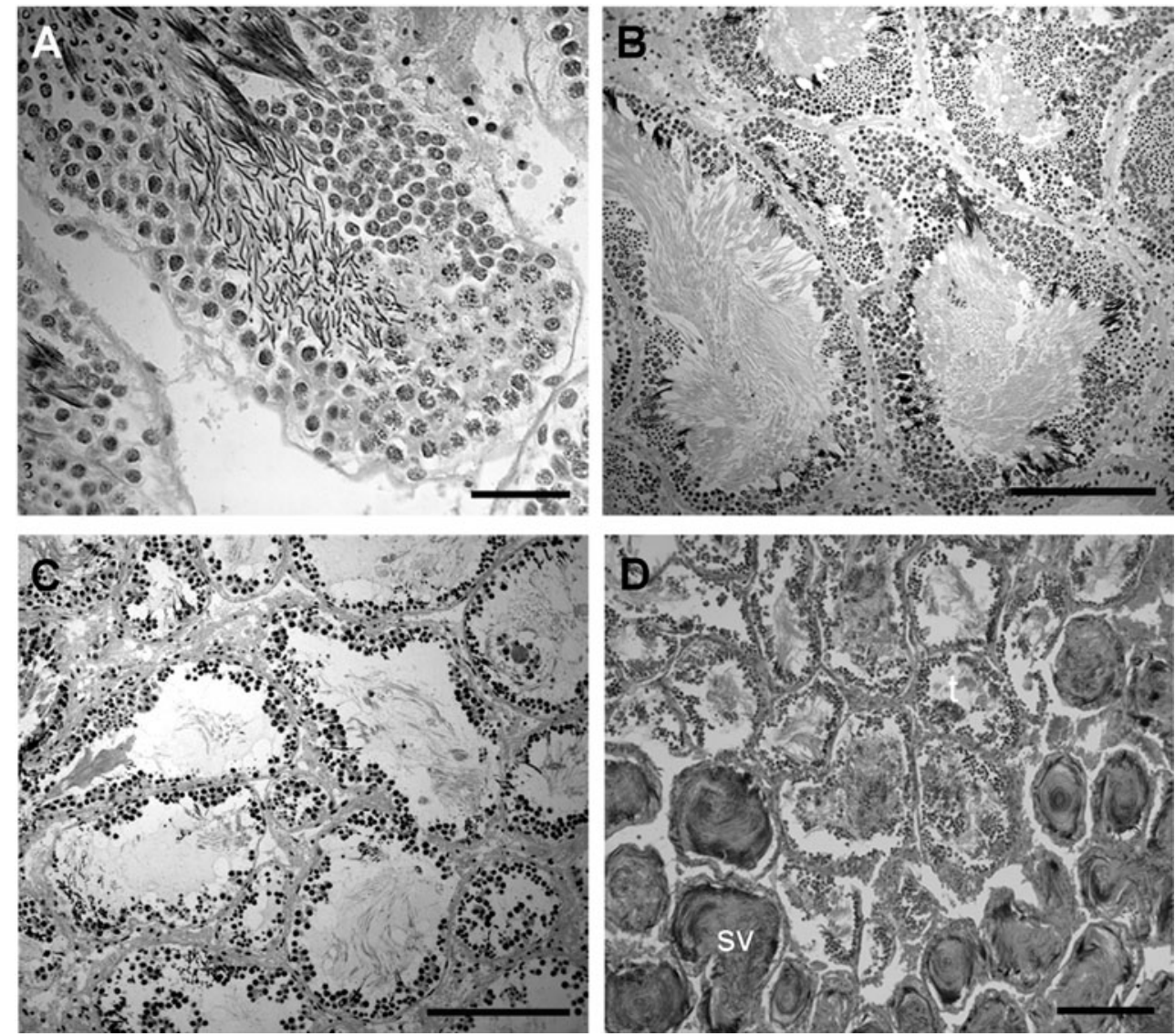

Fig. 6. Adelomelon beckii. Histology of male gonad showing developmental stages. (A) Developing: with the entire spermatic series. (B) Mature: spermatogenic tubule full of spermatozoa. (C) Spent: note the empty tubules. (D) Recovering: degrading spermatozoa free in the testis (t); note the seminal vesicle (sv) full of spermatozoa. Scale bars: $(A) 50 \mu m_{i}(B, C) 100 \mu m_{i}$ (D) $200 \mu \mathrm{m}$

\section{Imposex}

A total of 206 Adelomelon beckii individuals were analyzed to assess the occurrence of imposex in the Mar del Plata population. The incidence of imposexaffected females (whose sex was confirmed in histological sections) was $1.53 \%$ and RPLI was 51.72. In females with imposex, a vas deferens and a penis were observed, but the vaginal opening was not blocked by the vas deferens, indicating a VDS Stage 3. Some females presented genital malformations, such as multiple penises (Fig. 8).

\section{DISCUSSION}

In the present study, female Adelomelon beckii clearly dominated in number over males, with an overall sex ratio of 2.07 . The predominance of females is common in species belonging to the suborder Neogastropoda (Feare 1970, McGwynne \& Van Der Horst
1985, Gibbs et al. 1988, Martel et al. 1986, Fretter \& Graham 1994, Olabarria \& Ramirez-Llodra 2004, Narvarte 2006). Nevertheless, the sex ratio varied throughout the year, especially during the reproductive season when females were more abundant than males. This pattern may reflect aggregations of mature females for communal spawning, as observed in other gastropods (Houston 1971, Kideys et al. 1993, Miloslavich \& Penchaszadeh 1997, Bigatti 2005), or males could remain buried while females were exposed on the bottom during egg-laying (Poppe \& Goto 1992). The availability and quality of hard substrata amongst otherwise soft sediment can strongly influence reproduction and oviposition in some neogastropods (Swanson 2004). Females of A. beckii require hard substrata on which to attach egg capsules (Penchaszadeh et al. 1999), and therefore bottom type might be responsible for aggregating individuals at an oviposition site. This pattern could also be due to the fact that, because females are bigger than males, the proportion of females is significantly higher in com- 

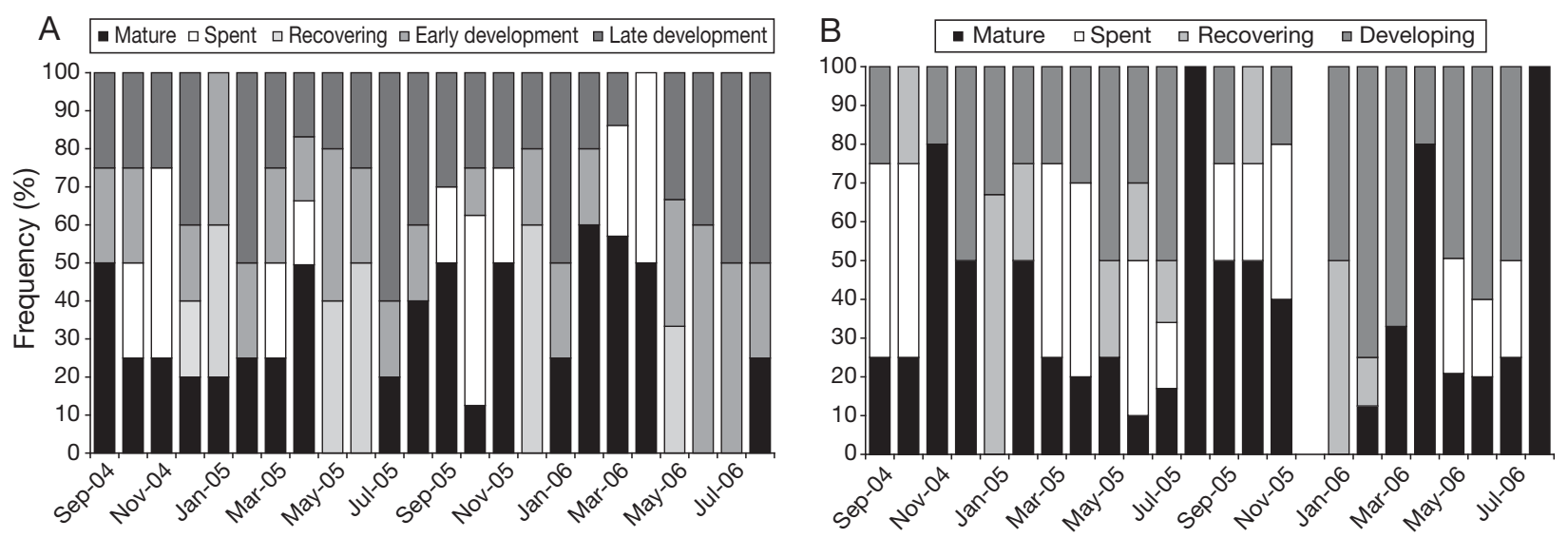

Fig. 7. Adelomelon beckii. Monthly variation in maturation stages in the ovary (A) and testis (B) of A. beckii from Mar del Plata

mercial catches where bigger animals are retained (Narvarte 2006) due to the size-selectivity of the fishing gears. For this reason, the real sex ratio of $A$. beckii needs to be confirmed by using non-selective sampling methods.

\section{Gonadal structure and gametogenesis}

The general structure of the gonads of Adelomelon beckii does not differ from that of other volutids (Giménez \& Penchaszadeh 2002, Cledón et al. 2005a, Bigatti et al. 2008, Penchaszadeh et al. 2009).

Table 2. Adelomelon beckii. Monthly variation in oocyte diameter $(\mu \mathrm{m})$ in female $A$. beckii. n: number of oocytes

\begin{tabular}{|lccc|}
\hline Date & Oocyte diameter & Mean $\pm \mathrm{SD}$ & $\mathrm{n}$ \\
\hline Sep 04 & $10-175$ & $40.17 \pm 9.42$ & 213 \\
Oct 04 & $12-119$ & $36.61 \pm 4.88$ & 388 \\
Nov 04 & $12-105$ & $35.72 \pm 11.06$ & 103 \\
Dec 04 & $12-105$ & $37.45 \pm 9.85$ & 208 \\
Jan 05 & $12-114$ & $29.0 \pm 7.01$ & 102 \\
Feb 05 & $15-156$ & $32.62 \pm 9.10$ & 137 \\
Mar 05 & $15-144$ & $31.02 \pm 8.65$ & 112 \\
Apr 05 & $20-118$ & $39.04 \pm 9.73$ & 88 \\
May 05 & $12-87$ & $42.33 \pm 5.67$ & 134 \\
Jun 05 & $17-95$ & $46.86 \pm 15.02$ & 187 \\
Jul 05 & $15-213$ & $53.22 \pm 24.76$ & 261 \\
Aug 05 & $15-156$ & $44.35 \pm 7.79$ & 455 \\
Sep 05 & $15-222$ & $73.45 \pm 19.55$ & 229 \\
Oct 05 & $15-104$ & $30.36 \pm 7.26$ & 298 \\
Nov 05 & $12-144$ & $49.96 \pm 7.32$ & 229 \\
Dec 05 & $20-97$ & $47.25 \pm 5.41$ & 74 \\
Jan 06 & $15-119$ & $38.08 \pm 10.40$ & 215 \\
Feb 06 & $15-187$ & $54.72 \pm 11.52$ & 198 \\
Mar 06 & $15-114$ & $48.74 \pm 13.23$ & 333 \\
Apr 06 & $20-151$ & $72.33 \pm 8.29$ & 135 \\
May 06 & $17-98$ & $45.87 \pm 13.17$ & 110 \\
Jun 06 & $17-144$ & $51.45 \pm 5.90$ & 178 \\
Jul 06 & $17-146$ & $52.95 \pm 6.61$ & 79 \\
Aug 06 & $15-154$ & $63.07 \pm 9.20$ & 98 \\
\hline
\end{tabular}

The ovary is formed by multiple tubules, containing only developing oocytes and associated accessory cells. de Jong-Brink et al. (1983) distinguished 3 categories of oocyte-follicle cell relationships, depending upon the number and arrangement of the follicle cells. In the first type, the oocyte is completely surrounded by an increasing number of follicle cells; in the second type, the oocyte is surrounded by a small, distinct number of follicle cells; and in the third type, a small number of follicle cells surround the oocyte only during the early stages of oogenesis. The observations made in the present study correspond to the first type of relationship, with the oocytes of Adelomelon beckii always surrounded by a great number of follicle cells, something rare in gastropods. The close relationship between follicle cells and oocytes during oocyte growth and the presence of gap junctions during vitellogenesis suggest the exchange of small molecules and ions between follicle cells and oocytes (Pipe 1987a).

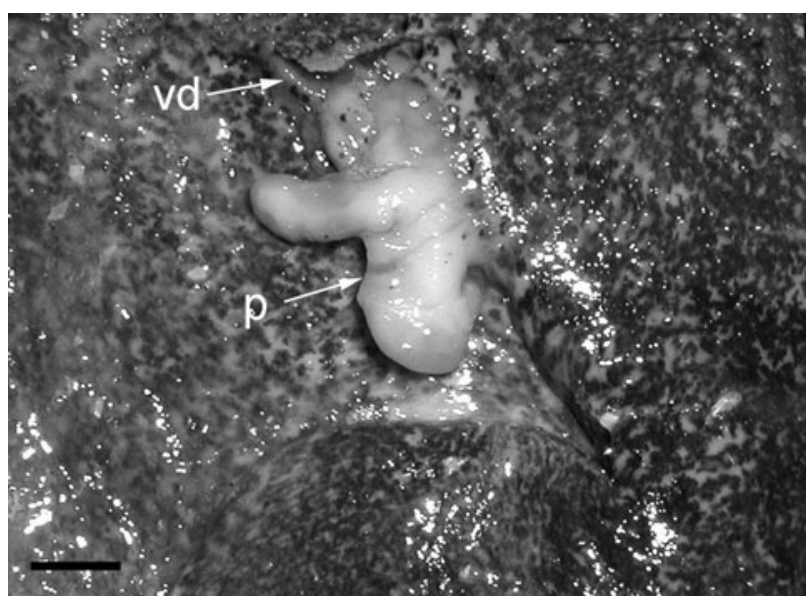

Fig. 8. Adelomelon beckii. Imposex-affected female, showing the presence of a penis (p) and vas deferens (vd). Scale bar: $1 \mathrm{~cm}$ 
Oogonia occurred in small groups and contained mitochondria endoplasmic reticulum and vacuoles. The large cytoplasm of previtellogenic oocytes is indicative of the onset of cellular growth. Morphological modification, proliferation of organelles and active synthesis of intracellular inclusions, occurred in vitellogenic oocytes. The early vitellogenesis of Adelomelon beckii is characterized by proliferation of endoplasmic reticulum, mitochondria and lipid droplets. Although many authors have reported the formation of lipid droplets in several bivalve species (Pipe 1987b, Dorange \& Le Pennec 1989, De Gaulejac et al. 1995), no clear morphological evidence of processes involved in lipid droplet formation were detected in the present study. In later stages of vitellogenesis, the cytoplasm is characterized by the presence of membrane-bound yolk granules and pinocytic vesicles. The present study indicates that $A$. beckii produces yolk granules by both auto- and heterosynthesis. Autosynthesis was documented by the increase in the number of proteosynthetic organelles and heterosynthesis by the formation of pinocytic vesicles, in which endocytosis of macromolecules appear to take place. The formation of yolk by autosynthesis is widespread in mollusks (Wourms 1987, Eckelbarger \& Davis 1996) and has been suggested to be the primary yolk-forming means in this phylum (de Jong-Brink et al. 1983). Nevertheless, the incorporation of exogenous yolk precursors by endocytosis is also well documented (Hill \& Bowen 1976, West 1981, Bottke et al. 1982, Pal \& Hodgson 2002).

Oocyte degeneration and resorption in mollusks is a commonly observed phenomenon (de Jong-Brink et al. 1983). In Adelomelon beckii there is considerable morphological evidence for phagocytosis of material by follicle cells, with a well-developed lysosomal system for breakdown, as well as remarkable amounts of rough endoplasmic reticulum for synthesis. Therefore, for the first time there is evidence to suggest their involvement in the resorption of material from degenerating oocytes.

The testis of Adelomelon beckii is also similar to other volutids (Giménez \& Penchaszadeh 2002, Cledón et al. 2005a, Bigatti et al. 2008, Penchaszadeh et al. 2009), as are the general features of spermatogenesis and sperm morphology (Giménez et al. 2008, 2009, Zabala et al. 2009), which are detailed in Arrighetti (2009), Giménez et al. (2009) and Arrighetti \& Giménez (2010).

\section{Reproductive cycle}

The proportion of individuals in different maturation stages showed marked seasonal variation and the oocyte size structure showed a distinct annual pattern.
Two major spawning events were identified: a spawning period between September and November (austral spring) and another between March and April (austral autumn). There was no apparent resting period in the reproductive cycle. The onset of breeding occurred at about the same time during the 2 yr study period. After spawning, the remaining oocytes degenerated and reappeared again mainly in December and May.

This pattern shows a clear seasonality that could be related to seawater temperature, an important environmental factor that regulates gonadal development and spawning in many gastropod species (Giese \& Pearse 1977, Hayashi 1980, Martel et al. 1986, Fretter \& Graham 1994, Giménez \& Penchaszadeh 2002, Ilano et al. 2003, Cledón et al. 2005a). It is possible that a slight change in seawater temperature might drastically influence spawning. Female spawning occurred when seawater temperature was lowest $\left(9^{\circ} \mathrm{C}\right.$ in October) and highest $\left(17^{\circ} \mathrm{C}\right.$ in $\mathrm{March}$ ) (for the monthly record of bottom seawater temperature see Carreto et al. 1998, Guerrero et al. 1999, Giménez \& Penchaszadeh 2002). These observations are in agreement with Giménez \& Penchaszadeh (2002) and Cledón et al. (2005a) on 2 other volutes from the same area: Zidona dufresnei and Adelomelon brasiliana, respectively.

All stages of spermatogenesis were found in all mature males, indicating a continuous production of sperm throughout the year. Mature spermatozoa in the testicular tubules and seminal vesicle were observed during the entire study period (except in January), even though different gametogenic stages were observed in the same individual at the same time. Similar results were found in 4 other volutid species: Zidona dufresnei (Giménez \& Penchaszadeh 2002), Adelomelon brasiliana (Cledón et al. 2005a), A. ancilla (Penchaszadeh et al. 2009) and Odontocymbiola magellanica (Bigatti et al. 2008). The existence of mature males during periods when females were not ripe has also been observed in the muricids Bolinus brandaris (Ramón \& Amor 2002) and Hexaplex trunculus (Vasconcelos et al. 2008). This pattern could be interpreted as a strategy to improve reproductive success. During copulation, the penis deposits the sperm into the bursa copulatrix of the female, where the sperm can be stored for a short period before fecundation and spawning takes place (Fretter 1980, Fretter \& Graham 1994). Thus the long period of maturity would allow males to increase the number of copulations and fertilize more females during a single breeding season. The present study suggests that in $A$. beckii seawater temperature is unlikely to affect male gonadal maturation. According to Martel et al. (1986), the presence of sperm in the pallial oviduct of females after copulation may possibly induce them to search for egg-laying sites, but the intensity of egg-laying may be affected by temperature. 


\section{Imposex}

The present study comprises the first record on the occurrence of imposex in Adelomelon beckii and is the first report of this genital abnormality in an offshore species from this area. Imposex is a widespread phenomenon caused by tributyltin (TBT), a compound used in antifouling paint (Gibbs et al. 1988, 1991, 1997), and has been reported in several coastal gastropods, particularly in species associated with harbour waters (Santos et al. 2000, Bech 2002, Bigatti et al. 2009). The Mar del Plata harbour is the most important fishing harbour in Argentina, with a coastal and offshore fleet of more than 300 vessels (Errazti \& Bertolotti 1998). In the Mar del Plata region, imposex has been reported for other gastropods, all associated with the harbour (Penchaszadeh et al. 2001, Cledón et al. 2006, Teso \& Penchaszadeh 2009). Though the percentage of imposex-affected females was low, the high RPLI indicates a higher sensitivity of $A$. beckii to TBT in comparison to other snails studied in Mar del Plata (Penchaszadeh et al. 2001, Cledón et al. 2006, Bigatti et al. 2009, Teso \& Penchaszadeh 2009).

\section{Fishery management}

Adelomelon beckii has been increasingly consumed in Mar del Plata in recent years and its fishery is important for the local economy. The current overexploitation regime (Arrighetti 2009) will be unsustainable in the long term, unless an adequate management plan is implemented. Overexploitation is potentially more severe in a population affected by imposex, given that imposex is known to affect the reproductive activity of the affected population. The present results, together with the estimation of the size at first sexual maturity (Arrighetti 2009), should be taken into account when implementing fishery management measures. According to the present data, a closed season should be established at least from September to November, when the most intense spawning events occur. Without proper management, this valuable fishing resource will be reduced to insignificant levels in Mar del Plata within a short period of time.

Acknowledgements. We thank A. and A. Meyer for their help during field sampling and C. Sanchez Antelo for laboratory assistance. Thanks are also due to J. Giménez and J. Pearse for their valuable comments on the draft version of this manuscript and J. Antonides for improving the English language. F.A. thanks CONICET for her PhD fellowship and the Constance Boone Grant for Malacology (2005) for the additional support. This work was partially funded by PICT 14419, PIP 5301 and PIP 2788.

\section{LITERATURE CITED}

Arrighetti F (2009) Reproduction, ultrastructure and growth of the giant snail Adelomelon beckii (Broderip 1836) off Mar del Plata, Argentina. PhD thesis, Universidad de Buenos Aires

Arrighetti F, Giménez J (2010) Ultrastructure of euspermatozoa and paraspermatozoa in the marine gastropod Adelomelon beckii (Caenogastropoda, Volutidae). Helgol Mar Res doi:10.1007/s10152-009-0184-5

- Bech M (2002) Imposex and tributyltin contamination as a consequence of the establishment of a marina, and increasing yachting activities at Phuket Island, Thailand. Environ Pollut 117:421-429

Bigatti G (2005) Anatomía, ecología y reproducción del caracol rojo Odontocymbiola magellanica (Gastropoda: Volutidae) en golfos norpatagónicos. PhD thesis, Universidad de Buenos Aires

Bigatti G, Penchaszadeh PE, Cledón M (2007) Age and growth in Odontocymbiola magellanica (Gastropoda: Volutidae) from Golfo Nuevo, Patagonia, Argentina. Mar Biol 150:1199-1204

> Bigatti G, Marzinelli EM, Penchaszadeh PE (2008) Seasonal reproduction and sexual maturity in Odontocymbiola magellanica (Neogastropoda, Volutidae). Invertebr Biol 127:314-326

Bigatti G, Primost MA, Cledón M, Averbuj A and others (2009) Biomonitoring of TBT contamination and imposex incidence along $4700 \mathrm{~km}$ of Argentinean shoreline (SW Atlantic: From 38S to 54S). Mar Pollut Bull 58:695-701

Bottke W, Sinha I, Keil I (1982) Coated vesicle-mediated transport and deposition of vitellogenic ferritin in the rapid growth phase of snail oocytes. J Cell Sci 53:173-191

Carranza A, Scarabino F, Ortega L (2008) Distribution of large benthic gastropods in the Uruguayan continental shelf and Río de la Plata Estuary. J Coast Res 24:161-168

Carreto JI, Akselman R, Montoya NG, Negri RM, Benavides HR, Carignan MO, Cucchi Colleoni AD (1998) Alexandrium tamarense bloom dynamics and Mytilus edulis toxicity in the coastal waters of Mar del Plata (Argentina). In: Reguera B, Blanco J, Fernández ML, Wyatt T (eds) Proceedings of the International Conference on Harmful algae. IOC/UNESCO, Vigo, p 135-138

Cledón M, Penchaszadeh PE, Arntz W (2005a) Gonadal cycle in an Adelomelon brasiliana (Neogastropoda: Volutidae) population off Buenos Aires province, Argentina. Mar Biol 147:439-445

> Cledón M, Brey T, Penchaszadeh PE, Arntz W (2005b) Individual growth and somatic production in Adelomelon brasiliana (Gastropoda; Volutidae) off Argentina. Mar Biol 147:447-452

> Cledón M, Theobald N, Gerwinski W, Penchaszadeh PE (2006) Imposex and organotin compounds in marine gastropods and sediments from the Mar del Plata coast, Argentina. J Mar Biol Assoc UK 86:751-755

> De Gaulejac B, Henry M, Vicente N (1995) An ultrastructural study of gametogenesis of the marine bivalve Pinna nobilis (Linnaeus 1758) I. Oogenesis. J Molluscan Stud 61:375-392

de Jong-Brink M, Boer HH, Joose J (1983) Mollusca. In: Adiyodi KG, Adiyodi RG (eds) Reproductive biology of invertebrates, Vol I. Oogenesis, oviposition and oosorption. Wiley \& Sons, London, p 297-355

> Dorange G, Le Pennec M (1989) Ultrastructural study of oogenesis and oocytic degeneration in Pecten maximus from the Bay of St. Brieuc. Mar Biol 103:339-348

Eckelbarger KJ, Davis CV (1996) Ultrastructure of the gonad 
and gametogenesis in the eastern oyster, Crassostrea virginica. I. Ovary and oogenesis. Mar Biol 127:79-87

Errazti E, Bertolotti MI (1998) Flota costera, descripción de las principales características en la región bonaerense. Frente Marit 17:63-71

Feare CJ (1970) The reproductive cycle of the dog whelk (Nucella lapillus). Proc Malacol Soc Lond 39:125-137

Fretter V (1980) Observations on the gross anatomy of the female genital duct of British Littorina species. J Molluscan Stud 46:148-153

Fretter V, Graham A (1994) British prosobranch molluscs: their functional anatomy and ecology. The Ray Society, London

Gibbs PE, Bryan GW (1994) Biomonitoring of tributyltin (TBT) pollution using the imposex response of neogastropod molluscs. In: Kramer KJM (ed) Biomonitoring of coastal waters and estuaries. CRC Press, Boca Raton, FL, p 205-226

Gibbs PE, Pascoe PL, Burt GR (1988) Sex change in the female dog-whelk, Nucella lapillus, induced by tributyltin from antifouling paints. J Mar Biol Assoc UK 68:715-731

Gibbs PE, Bryan GW, Pascoe PL (1991) TBT-induced imposex in the dogwhelk, Nucella lapillus: geographical uniformity of the response and effects. Mar Environ Res 32:79-87

Gibbs PE, Bebianno MJ, Coelho MR (1997) Evidence of the differential sensitivity of neogastropods to tributyltin (TBT) pollution, with notes on a species (Columbella rustica) lacking the imposex response. Environ Technol 18:1219-1224

Giese AC, Pearse JS (1977) Molluscs: gastropods and cephalopods. In: Giese AC and Pearse JS (eds) Reproduction of marine invertebrates, Vol IV. Academic Press, New York, p 1-102

Giménez J, Penchaszadeh PE (2002) Reproductive cycle of Zidona dufresnei (Caenogastropoda: Volutidae) from the southwestern Atlantic Ocean. Mar Biol 140:755-761

Giménez J, Brey T, Mackensen A, Penchaszadeh PE (2004) Age, growth and mortality of the prosobranch snail Zidona dufresnei (Donovan, 1823) in the Mar del Plata area, SW Atlantic Ocean. Mar Biol 145:707-712

Giménez J, Lasta M, Bigatti G, Penchaszadeh PE (2005) Exploitation of the volute snail Zidona dufresnei in Argentine waters, southern Atlantic Ocean. J Shellfish Res 24: $1135-1140$

Giménez J, Healy JM, Hermida G, Nostro FL, Penchaszadeh PE (2008) Ultrastructure and potential taxonomic importance of euspermatozoa and paraspermatozoa in the volutid gastropods Zidona dufresnei and Provocator mirabilis (Caenogastropoda, Mollusca). Zoomorphology 127:161-173

Giménez J, Arrighetti F, Teso SV, Hermida GN, Zabala S, Penchaszadeh PE (2009) Sperm morphology of two marine neogastropods from the southwestern Atlantic Ocean (Caenogastropoda: Volutidae, Olividae). Nautilus 123:1-6

Guerrero RA, Lasta CA, Acha EM, Mianzan HW, Framinñan MB (1999) Atlas hidrográfico del Río de la Plata. Instituto Nacional de Desarrollo Pesquero, Buenos Aires, Montevideo

Hayashi I (1980) The reproductive biology of the ormer, Haliotis tuberculata. J Mar Biol Assoc UK 60:415-430

Hill RS, Bowen ID (1976) Studies on the ovotestis of the slug Agriolimax reticulatus (Müller). Cell Tissue Res 173: 465-482

Houston RS (1971) Reproductive biology of Thais emarginata (Deshayes, 1839) and Thais canaliculata (Duclos, 1832). Veliger 13:348-357

Ilano AS, Fujinaga K, Nakao S (2003) Reproductive cycle and size at sexual maturity of the commercial whelk Buccinum isaotakii in Funka Bay, Hokkaido, Japan. J Mar Biol Assoc UK 83:1287-1294

Kideys AE, Nash RDM, Hartnoll RG (1993) Reproductive cycle and energetic cost of reproduction of the neogastropod Buccinum undatum in the Irish Sea. J Mar Biol Assoc UK 73:391-403

> Martel A, Larrivée D, Klein KR, Himmelman JR (1986) Reproductive cycle and seasonal feeding activity of the neogastropod Buccinum undatum. Mar Biol 92:211-221

McGwynne LE, Van Der Horst G (1985) Patterns of reproduction in three sandy beach whelks of the genus Bullia Griffith. J Molluscan Stud 51:190-197

Miloslavich P, Penchaszadeh PE (1997) Spawn and development of Fusinus closter Philippi, 1850 (Gastropoda: Prosobranchia) from the Venezuelan Caribbean. Veliger 40: 93-100

Narvarte MA (2006) Biology and fishery of the whelk Buccinanops globulosum (Kiener, 1834) in northern coastal waters of the San Matías Gulf (Patagonia, Argentina). Fish Res 77:131-137

Olabarria C, Ramirez-Llodra E (2004) Reproductive strategies of two deep-sea gastropod species from the Porcupine Seabight (Northeast Atlantic). Mar Biol 145:541-549

Pal P, Hodgson AN (2002) An ultrustructural study of oogenesis in a planktonic and a direct-developing species of siphonaria (Gastropoda: Pulmonata). J Molluscan Stud 68: 337-344

Penchaszadeh PE, Miloslavich P, Lasta M, Costa PMS (1999) Egg capsules in the genus Adelomelon (Caenogastropoda: Volutidae) from the Atlantic coast of South America. Nautilus 113:56-63

> Penchaszadeh PE, Averbuj A, Cledón M (2001) Imposex in gastropods from Argentina (south-western Atlantic). Mar Pollut Bull 42:790-791

Penchaszadeh PE, Sanchez Antelo C, Zabala S, Bigatti G (2009) Reproduction and imposex in the edible snail Adelomelon ancilla from northern Patagonia, Argentina. Mar Biol 156:1929-1939

- Pipe RK (1987a) Oogenesis in the marine mussel Mytilus edulis: an ultrastructural study. Mar Biol 95:405-414

> Pipe RK (1987b) Ultrastructural and cytochemical study on interactions between nutrient storage cells and gametogenesis in the mussel Mytilus edulis. Mar Biol 96:519-528

Poppe GT, Goto Y (1992) Volutes. L'Informatore Piceno, Ancona

Ramón M, Amor JM (2002) Reproductive cycle of Bolinus brandaris and penis and genital duct size variations in a population affected by imposex. J Mar Biol Assoc UK 82: $435-442$

Riestra G, Fabiano G (2000) Moluscos gasterópodos de interés socioeconómico para el Uruguay. Recursos pesqueros no tradicionales: moluscos bentónicos marinos. Proyecto URU/92/003. INAPE, Montevideo, p 75-141

Rios EC (1994) Seashells of Brazil, 2nd edn. Fundaçäo Universidade do Rio Grande, Rio Grande

Santos MM, Vieira N, Santos AM (2000) Imposex in the dogwhelk Nucella lapillus (L.) along the Portuguese Coast. Mar Pollut Bull 40:643-646

> Swanson CA (2004) Effect of substrate availability and conspecific cues on communal oviposition in the apple murex snail Phyllonotus pomum. Mar Ecol Prog Ser 275:175-184

- Teso SV, Penchaszadeh PE (2009) Beach filling and imposex in Olivancillaria deshayesiana (Mollusca: Gastropoda: Olividae) from the coast of Mar del Plata, Argentina. J Mar Biol Assoc UK 89:557-562

- Vasconcelos P, Lopes B, Castro M, Gaspar MB (2008) Gametogenic cycle of Hexaplex (Trunculariopsis) trunculus (Gas- 
tropoda: Muricidae) in the Ria Formosa lagoon (Algarve coast, southern Portugal). J Mar Biol Assoc UK 88:321-329 Weaver CS, du Pont JE (1970) Living volutes. A monograph of the recent Volutidae of the world. Delaware Museum of Natural History, Greenville, DE, p 1-375

West DL (1981) Reproductive biology of Colus stimpsoni (Prosobranchia: Buccinidae) 4. Oogenesis. Veliger 24:28-38 Wourms JP (1987) General aspects: seeking unity in diver-

Editorial responsibility: Riccardo Cattaneo-Vietti, Genova, Italy sity. In: Giese AC, Pearse JS (eds) Reproduction of marine invertebrates, Vol IX. Academic Press, New York, p 49-178

Zabala S, Hermida G, Giménez J (2009) Ultrastructure of euspermatozoa and paraspermatozoa in the volutid snail Adelomelon ancilla (Mollusca: Caenogastropoda). Helgol Mar Res 63:181-188

Submitted: October 15, 2009; Accepted: January 26, 2010 Proofs received from author(s): March 10, 2010 